\title{
The State of the Process of Decentralisation in Cameroon
}

\author{
Cosmas Cheka*
}

\begin{abstract}
The pace of the process of decentralisation in a given context unavoidably depends on the degree of favourableness of the legal environment and the dynamism of stakeholders (especially of local authorities, the state, development cooperation partners and civil society). This paper seeks to inform on the state of the process in Cameroon by exposing its current legal environment, its constraints and the level of organisation of its key actors in relation to the legal environment. Drawing from this assessment, the paper assesses the shortcomings of the decentralisation process in Cameroon while arguing that the objective for embarking on decentralisation in each context varies with its promoter. In the case of Cameroon, decentralisation constitutes the legal, institutional and financial means through which regional and local authorities operate to foster local development with the active involvement of the population. Through the devolution of powers to local entities, local development could be enhanced and a contribution made to the fight against poverty. The assessment of the legal framework and of its stakeholders shows that the decentralisation laws passed in 2004 in Cameroon have local development and governance as their main thrust. The new laws certainly create an environment that represents an irreversible step forward for the process of decentralisation but are in need of completion by the passing of legal instruments of application for them to effectively accelerate the pace of the decentralisation process and good governance. There is also need for better organisation and coordination of interventions of the stakeholders. The process is currently hampered by especially financial constraints on local authorities and limited capacities of the actors and beneficiaries of devolved powers. The paper concludes with a plea in favour of inter alia
\end{abstract}

* Faculty of Political \& Legal Sciences, University of Yaounde II at Soa, Cameroon.Email: cosmas4@dschangshuss.net or ccosmas4@yahoo.com 
the strengthening of the capacities of all stakeholders through an approach that is sustainable if the objective of decentralisation is to be met.

\section{Résumé}

Dans chaque contexte, le processus de décentralisation dépend inévitablement des opportunités qu'offrent l'environnement juridique et du dynamisme des acteurs (surtout les collectivités locales, l'État, les partenaires au développement, la société civile). A travers une analyse de l'environnement juridique, de ses contraintes et du niveau d'organisation des acteurs clés, le présent article a pour objet d'informer sur l'état des lieux de la décentralisation au Cameroun. Sur la base de l'analyse juridique, les défaillances du processus sont identifiées avec une argumentation suivant laquelle l'objectif de la décentralisation varie dans chaque contexte selon son promoteur. Pour le Cameroun, la décentralisation constitue le moyen légal, institutionnel et financier par lequel les collectivités locales œuvrent en faveur du développement local avec l'implication active des populations. Le transfert des compétences aux collectivités locales participe à la mise en œuvre du développement local et la lutte contre la pauvreté. L’analyse du cadre juridique montre que le développement local et la gouvernance sont au centre des lois camerounaises. Certes ces nouvelles lois créent un environnement qui est un pas irréversible en faveur de la décentralisation. Néanmoins elles attendent d'être complétées par des textes d'application afin d'accélérer véritablement le processus. De plus, l'environnement lui-même a besoin d'une meilleure organisation et coordination des intervenants. Les contraintes financières des collectivités locales et les faibles capacités des intervenants et bénéficiaires des pouvoirs transférés, comptent parmi les contraintes majeures identifiées. Cette étude conclut avec la remarque que ce sont ces constats qui justifient un plaidoyer en faveur du renforcement des capacités des intervenants à travers un approche durable, si on veut atteindre l’objectif de la décentralisation au Cameroun.

\section{Introduction}

Institutional reform in African countries in recent years has been marked by trials of various forms of decentralisation. In general, hitherto centralised governments have initiated a reform agenda with the aim of transferring some powers, tasks and resources to regional governments and local authorities. Cameroon is one of these countries.

Cameroon experienced different forms of decentralisation before the 1990s. Decentralisation in its current form here is based notably on the Constitution embodied in Law No. 96/06 of 18 January 1996. On the strength of the provisions of article 55 of the said constitution, 'decentralised local entities of the Republic shall be regions and councils ... decentralised local authorities shall be legal entities recognised by public law. They shall enjoy administrative and financial autonomy in the management of local interests. 
They shall be freely administered by boards elected in accordance with conditions laid down by law'. In Cameroon therefore, decentralisation constitutes part of the framework of national policy on democratisation that started in the 1990s. ${ }^{1}$

The pace of the process of decentralisation in a given context unavoidably depends on the degree of favourableness of the legal environment and the dynamism of stakeholders (especially of local entities, the state, development cooperation partners and civil society). This paper seeks to inform on the state of the process of decentralisation in Cameroon by considering the current legal environment, constraints and the level of organisation of its key actors in relation to the legal environment. To this end an overview of the objective of decentralisation is useful.

\section{The objective of decentralisation: A brief overview}

The ultimate goal of reforms that decentralise centralised systems differs depending on whether its promoter is the state or part of the community of donors. States embark on decentralisation with the objective of bringing the government closer to the people and thereby involve them more actively in the process of development. ${ }^{2}$ Decentralisation 'furthers popular participation' (Midgley 1986). R Lemarchand (1998) and Marc Totté et al., (2003), however, doubt that decentralisation per se enhances participation of the masses in development. Donors and some theorists like Wunsch et al., (1990), Cheema et al. (1983), and Esman et al. (1984), on their part, view decentralisation as a means of combating corruption and alleviating poverty; considering that decentralisation provides avenues for participatory management and better use of available resources. Sawadogo (2001) is of the view that decentralisation constitutes an excuse for treating diverse problems: 'good governance, development, democracy, poverty alleviation, administrative reform, privatisation etc. at the same time'. In this paper, the state of decentralisation is perceived as the institutional and financial means through which regional and local governments operate to foster local development and governance with the active involvement of the population. By the same token, decentralisation contributes in combating corruption and alleviating poverty.

\section{The legal environment}

Three bills ${ }^{3}$ voted by the Cameroonian House of Parliament in June 2004 were promulgated into law on July 22, 2004. These laws replace the hitherto disparate laws of 1974 on local councils with their multitude of subsequent amendments. 
Under the provisions of the laws of 2004, there is a devolution of powers accompanied by the transfer of means, financial, material and human, to local entities that are made of 10 regions and 339 councils. ${ }^{4}$ The President of the Republic can by decree create or redelimit the geographical boundaries of a local authority as well as rename or decide on the temporary regrouping of local authorities. ${ }^{5}$ Moreover a common decentralisation fund is created (article 23(1), Orientation Law). For the steering and evaluation of the decentralisation process there is a national decentralisation council and an inter-Ministerial Committee ${ }^{6}$ of local services (article 79, Orientation law). These new laws (that essentially focus on local development and governance) constitute the basic framework of rules on decentralisation in Cameroon.

Prior to July 2004, local entities were endowed with largely social functions like the celebration of marriages and delivery of birth and death certificates (1974 law relating to councils). In the transfer of powers for local development under the 2004 laws, local authorities are assigned the task of promoting economic, social, health, educational, cultural and sports development (article 4(1), Law of Orientation). Powers that correspond to the promotion of development in these sectors are devolved to local authorities under conditions laid down by law (articles 18-24 of Rules applicable to Regions; articles 15-22 of Rules applicable to Councils). The development opportunities implied in the execution of these tasks are new to local authorities in Cameroon. Here, the local authority can only act as catalyst to local development by at least strengthening municipal infrastructure (especially social infrastructure), carrying out a broad range of activities under the heading of 'governance' (institutional capacity building of local government structures as well as civil society organisations and especially the interface between them) and an endowment with the capacity to lead local development for wealth creation. This way, devolved powers will greatly contribute in serving development.

The decentralisation laws of 2004 further set the pattern of the exercise of power by local authorities which represents the framework for governance and democratic practice. Local authorities are endowed with legal personality and administrative autonomy by law. These structures are administered by entities whose organs are elected through direct universal suffrage. The activities of these elected local entities are overseen by the representative of the supervisory authority, that is, the Governor and the Senior Divisional Officer at the level of the region and the council respectively (articles 46-57 of the Orientation Law). Local officials are not only accountable to the electorate but to the Chief Executive of the state too. The latter can dismiss an elected official for embezzlement (article 95(1) Orientation law). 
Each local authority has two organs, one deliberative and the other executive. To increase dialogue over municipal matters, there are four statutory meetings (unlike two under the $1974 \mathrm{Law}$ ). Local authorities are empowered to undertake decentralised cooperation and form unions of councils (article 131 Orientation law). On democratic practice within organs of local authorities, a quorum of two-thirds of the membership is required for a municipal council meeting to be held. Decisions are taken by simple majority vote and as a general rule council sessions are open to the public. Extracts of proceedings of council sessions must be communicated to the public eight days after the council session (art 40(1)).

The practice of having local governments that are elected directly by the population actively involves them in the choice of their local leaders who in turn are accountable or answerable to them. It is therefore evident that laws that define such a pattern of the exercise of power at local authority level enhance democratic practice and good governance. The attainment of this objective through laws that devolve such powers determines the process of decentralisation and contingent on the level of contextual constraints and the dynamism of its stakeholders.

\section{Stakeholders and Developments}

The stakeholders or actors of the process are the state, local authorities, civil society and development cooperation agencies, all of them exercising roles that are complementary.

\section{Development co-operation agencies}

Donors active in the decentralisation domain in Cameroon are the United Nations system, Germany, France, Canada, European Union, the Dutch ${ }^{7}$ and the Swiss ${ }^{8}$ governments. The UN system assisted in the elaboration of training manuals for elected councillors for use nationwide. The European Union and all of the bilateral stakeholders support the strengthening of the capacities of the local actors either at the level of the Ministry in charge of decentralisation (where there is a French technical adviser to the Minister) or at the level of specific local councils. For example, German technical and financial assistance (via a twelve-year programme that is split into three phases of four years each) is to be implemented by the combined effort of four technical organs ${ }^{9}$ in three regions that count 165 councils. This donor envisages carrying out capacity building in at most 25 of the 165 councils of the three regions ${ }^{10}$ by the end of the total programme phase of twelve years. Swiss assistance is limited to supporting capacity building in sixteen out of a total of 59 councils of the North West and South West Provinces of Cameroon. 
In effect therefore, the assistance of donors is thematic and limited in geographical scope to a few councils. Ideally, comprehensive assistance to the process should at least cover the strengthening of municipal infrastructure (especially social infrastructure), carrying out a broad range of activities under the governance heading (such as the capacity building of local government structures and civil society organisations as well as the interface between them) and assistance to councils for the strengthening of their capacity to lead local development for wealth creation.

The sheer enormity and the financial implications of assisting decentralisation nationwide perhaps explain the limitation of donor intervention to a relatively small number of councils and to a theme or two each time. Nevertheless, the donor community is interested in the decentralisation process.

\section{The Ministry in charge of local entities}

The creation of a Ministry of Territorial Administration and Decentralisation (MINATD) by Decree No. 2002/216 of 24 August 2002 seems to translate the will of the state to advance the process of decentralisation while at the same time taking into account imperatives of preserving national unity and social cohesion in a country characterised by social and cultural diversity. As the supervisory authority of regions and councils, MINATD ${ }^{11}$ is currently in the throes of a study that aims at reforming and aligning the system of administration to the advent of decentralisation. Besides, the National Governance Programme (PNG) (composed of a decentralisation and local development sub-commission) liaises with the Directorate in charge of councils in the MINATD towards the implementation of decentralisation. Also, the Local Government Training Centre (CEFAM) and the Special Inter-communal Equipment and Support Fund (FEICOM) are the other specialised state institutions under MINATD that are meant to assist the latter in the implementation of decentralisation.

FEICOM plays two useful roles for decentralisation. It collects and redistributes the additional council surtax and provides financial grants and soft loans to councils. The Local Government Training Centre (CEFAM) is responsible for providing training and refresher courses to municipal staff. Tenders for the reform of CEFAM and of FEICOM were advertised per interview of MINATD (2005) and declared abortive in October 2005. The objective of the latter tenders was to put in place support structures to MINATD that enhance the implementation of decentralisation.

On the very important subject of capacity building, MINATD has embarked on a vast training (in one week workshops) of municipal councillors and officials on leadership and council management, in partnership with development cooperation agencies. Six of the ten provinces have already been 
covered by this training programme (2005 Cameroon Tribune, interview with MINATD). The initiative to train councillors is welcome but though here, like in Francophone West African states as Totté et al. (2003: 29) remarked, 'peasant structures lack the capacity to ensure sustainable development'. ${ }^{12}$ The training modules are unfortunately mute on the subject of local development which is a key and new task of local entities. Moreover, the approach is severely flawed in being one of 'fire and forget', i.e. devoid of a clear and predictable follow-up strategy. It is common knowledge that sustainable local development requires proper supervision and monitoring mechanisms. The MINATD approach to training may also seem to be too paternalistic for assuming that councils alone are in need of capacity building. It is hoped that future training exercises will envisage the inclusion of all the other actors in the decentralisation process because it is common knowledge that focusing more on local officials ‘usually leads to local passivity' (Wunsch et al., 1990: 87).

\section{The Union of Councils and Cities of Cameroon (UCCC)}

The association of local councils (UCCC) was created in December 2003 by a fusion of two associations that brought together all the councils of Cameroon. UCCC has of late manifested an increasing dynamism both at provincial and national levels. National elections of officials of this association were held in May 2005 after a session of its General Assembly. These elections saw the participation of all the mayors of UCCC. A temporary Bureau that had been put in place by the General Assembly in December 2003 was re-elected into office until 2007. The national office of UCCC (formerly lodged at the offices of the Yaoundé 1 City Municipality) is now set up on neutral premises in the Bastos neighbourhood of Yaoundé.

In terms of marketing of the potential of local councils in the electronic age, UCCC now has a web-site: www.mairiesducameroun.net. This site posts a giant map of Cameroon showing the ten provinces (or regions under the 2004 laws) that in turn are broken up into 339 local councils. A page on the website is dedicated in the website for each of the 339 local councils wherein can be found a presentation of the council, a word from the Mayor, ongoing projects, a list of companies operating within the council, and current and useful addresses of the council area. The site also posts a summary of territorial administration of Cameroon and takes a brief overview of FEICOM.

Regarding local government activities, UCCC recently lodged a petition to the supervisory authority over the management and other shortcomings of FEICOM. The reaction of the supervisory authorities to this petition has been swift. For example, according to the newspaper, Le Quotidien Mutations, the board members of FEICOM at its meeting of July 2005, 'ex- 
pressed doubts over the sincerity of the accounts' presented by FEICOM's General Manager. Thereafter, the Minister in charge of finance promptly withdrew key government employees seconded to FEICOM by that Ministry (Le Quotidien Mutations, 2005). FEICOM's former Director General was not only dismissed but has been behind bars since 7 March 2006 on charges of embezzlement of public funds. This shows that UCCC (backed by its 339 council membership) is a force that can muster tremendous clout. The problem is that it is still very young as a structure and requires institutional, managerial and financial support for it to play its rightful role of a catalyst and oversight to the decentralisation reform agenda.

\section{Specialised civil society organisations}

There is an emergence of civil society organisations (CSOs) that specifically support the decentralisation process. The Centre des Nouvelles Alternatives d’Appui au Dévélopment (Canadel), ${ }^{13}$ Action pour le développement equitable et durable (ADEID), ${ }^{14}$ Alternatives Durables pour le Développement (ADD), Service d'Appui aux initiatives locales de développement (SAILD), ${ }^{15}$ Zenu Network $^{16}$ and Espace Dschangshuss pour la Gouvernance Citoyenne en Afrique Centrale ${ }^{17}$ constitute some of these CSOs. The written media counts Alert Gouvernance among organs specialised in the dissemination of information on decentralisation. A developed civil society will provide proper oversight of the decentralisation process. For the time being, these specific CSOs need better organisation, training and means if they must play their role in the process. They currently are weak.

\section{The larger political environment and the process}

Views and actions of the people as expressed by their elected representatives especially in the House of Parliament of Cameroon reflect those of the bulk of the political environment. Members of the 180-strong House of Parliament were disenchanted with the level of corruption and were convinced that decentralisation constitutes one strategy for curbing the evil. Parliament was then led to debate and vote the 2004 decentralisation laws when the bills were presented by the executive arm of the state. This is why and how far the people, through parliament, have manifested in favour of decentralisation as a political issue. The pace that would turn this manifestation of the will of the masses to effective reality depends however on completion of the laws by legal instruments of application signed by the Executive.

Otherwise, the foregoing is evidence of the linkage between the legal environment, stakeholders and the organisation of the latter which creates synergies that invigorate and accelerate pro-decentralisation initiatives and activities. The pace of the process nevertheless depends on the level of the constraints under which stakeholders operate. 


\section{Critique of the process}

\section{Legal instruments, vital missing links}

The new laws revisit the role and powers of supervisory authorities over local entities. ${ }^{18}$ Devolved powers on the subject of local development entail an adaptation of the relationships of deconcentrated government ministries with local authorities. This implicitly involves traditional and religious authorities, civil society organisations, and development cooperation agencies that have hitherto taken up local development initiatives alongside the state. The interface between all of these actors requires proper clarification. There is therefore a vast task of research, training, organisation and reform involved here. The result will enable each stakeholder, in the process, to master where their duties commence and end so that each of them plays an effective role in the process. On this score there is absence yet of legal instruments (laws, decrees and orders) completing aspects of the organisation and functioning of decentralised local authorities as provided for by the Constitution of 1996 and the laws of 2004. Most urgent are instruments of the law ${ }^{19}$ governing conditions for the election of regional councillors. The signing, publication and application of the latter will mark the effective birth of regions. Similarly, the law defining the financial system (régime financier) of local authorities as well as the relevant tax (fiscalité locale) system is awaited. So too is the effective setting up of the National Decentralisation Council, the Inter-ministerial Committee for local services and the decentralisation of the Administrative Bench of the Supreme Court that is currently centralised in Yaoundé; structures through which stakeholders can best oversee, influence and determine the pace of the decentralisation process. The operationalisation of the functioning of decentralised local services also depends on an awaited decree.

\section{Stakeholders need urgent accompaniment}

In general, the laws devolve powers to local authorities that are yet in need of the capacity to effectively manage the said powers. The laws therefore seem to be comparatively advanced and with this comes the risk that is comparable to liberalisation of the economies of African countries in the 1990s without first ensuring that they were competitive. ${ }^{20}$ There is a dire need for an accelerated and continuous capacity building of stake holders so as to neutralise whatever error there was in devolving power before training its beneficiaries on how to exercise the said powers. 


\section{Coordination of stakeholders by the supervisory authority awaited} Stakeholders in the decentralisation process today in Cameroon are like the proverbial colony of ants carrying a large cricket (decentralisation). It is said that when one sees a colony of ants carrying a large cricket, it is because they all know to where they are heading. It is submitted that this is not the case with development cooperation agencies and other stakeholders assisting in the decentralisation process in Cameroon. The latter currently seem to be doing so in the absence of coordination by the supervisory authority. A committee was recently created to serve this purpose, yet is well-nigh impossible as of now to immediately tell which donor or actor is doing what, where, with what resources, for how long and with what degree of success. This is because a recipient-driven coordination forum or mechanism for dialogue between all actors is yet to be put in place. In the absence of such a mechanism whereby MINATD spells out priorities of the process, the current multitude of actors (like ants without a sense of vision and in need of leadership) will, with all good intentions, continue to retard the process by duplicating efforts and wasting useful resources through dispersion.

\section{Decentralisation accompaniment structures wanting}

Structural readjustments of the state apparatus, especially those that are meant to accompany the implementation of decentralisation (like CEFAM and FEICOM), are awaited. FEICOM, created by the 1974 law $^{21}$ on local councils and reorganised in 2006, ${ }^{22}$ currently manages mainly the 'additional council tax' (with workings and procedures that do not yet permit a clear identification of its criteria for the distribution of resources). The law on the Orientation of Decentralisation (and corresponding provisions of the 2004 laws relating to Councils and Regions) in article 88 simply abrogates the 1974 law on local councils. It is submitted that a structure like FEICOM, that owes its birth to a law and that has apparently been killed by another is dead in the eyes of the law. The current legal status of FEICOM is therefore unclear.

\section{Pace of process hampered by constraints in the legal environment} A major constraint stems from Law $N^{\circ}$ 2004/018 of July 22, 2004 laying down rules applicable to councils. Article 115(1) of the latter law puts into question the principle of free administration of decentralised local entities, albeit by the creation of 'city councils' with special status. According to Boudine (1992), 'the essence of the autonomy of local authorities emanates from the mode of designation of their leaders by direct universal suffrage and the freedom of the deliberating assembly to define norms that bind them; with the proviso that they do not conflict with national law' ${ }^{23}$ The appointment of government delegates to head local authorities (even if of large cit- 
ies) introduces a unique twist into the classical meaning of 'autonomy of local authorities'. Although some theorists of constitutional law (Guimdo 1998; Troper 1980) seem to gloss over this fine point, it would appear that the appointment of these government delegates to lord over large cities in accordance with article 115(1) of the said Cameroonian law contradicts the principle of the free administration of local authorities by officials locally elected by direct universal suffrage, considering that government delegates are appointed by presidential decree. In such conditions, these municipal administrators are neither mayors nor municipal councillors attached to some local authority. This constitutes a serious setback especially at the level of the local entities where this provision is applied.

Were it indeed the case of large cities in an emerging democracy tampering with the principle laid down by law whereby local authorities 'shall be freely administered by boards elected in accordance with conditions laid down by law', it is submitted that there is a need to find alternatives that conform to the law. For example, the appointment of the government delegate in each case from amongst elected local councillors in one breath permits respect of the spirit of the law without expressly excluding avenues for the expression of the interest of government in the choice of officials charged with administering the cities. In the absence of such a formula, the introduction of the notion of government delegates questions the principle of elections as a means of designating municipal executives accountable to the electorate; thereby subverting the democratic and decentralisation process.

Again, the new laws seem to pay little attention to measures that stimulate appropriation of the decentralisation process by the population. For example as indicated earlier, the 2004 laws simply state in a top-down fashion that the President of the Republic can create, rename, and re-delimit geographical boundaries of local authorities. This approach relegates the participation of the masses in the definition of their own identity, albeit at local level, to the rear. ${ }^{24}$ This piece of legislation seems to directly contradict the political intention referred to earlier whereby the objective of decentralisation is to better involve the masses in the process of development. It is submitted that this contradiction and relegation is a clear and major obstacle to the appropriation of the process by those who ought to ensure proper oversight and success of the process.

The third serious constraint to the process of decentralisation lies in the centralisation of government financial resources as a result of the principle of a 'unicité de caisse' (single till) instituted by the finance law of 1962. Local councils were reminded to respect this principle by a May 2005 decision of the Minister in charge of Finance ordering all councils to close all accounts held by them in high street banks and to immediately transfer the 
proceeds into the national treasury. ${ }^{25}$ The financial status of councils, albeit 'autonomous' under the principle of 'unicité de caisse', becomes precarious because dependent on the liquidity situation of the state treasury. It has been argued that a repeal of this decision would weaken the state. However, it has to be admitted that its continuous maintenance is at the root of the current financial difficulties of local authorities. Efforts need to be made towards reforming this principle (as was the case in 1990 granting a special waiver in health matters relating to the provision of essential drugs in the health sector) for local authorities to effectively experience financial autonomy as provided by law.

\section{Apparent pussyfooting by the Executive in the application}

\section{of the law}

The pace of the process of decentralisation would seem to be retarded in part too by the Executive. It would appear that certain provisions of the law are not yet effective even though the 2004 decentralisation laws did not make them contingent upon the signing of legal instruments of application by the Executive. A glaring example of this has to do with ensuring that the council executive draws its legitimacy from the electorate of the council area. It is for this reason that the creation of 'special regime councils' 26 hitherto lorded over by government delegates appointed by decree was repealed by section 156 (1) of the 2004 law applicable to councils. More than two years after this repeal, however, the said delegates of 'special regime councils' are still in office, although the transitional and final provisions of the 2004 decentralisation laws apparently do not expressly state that they shall keep their positions, even for the time-being.

Though observers across the board agree that it is thanks to the government of August $2002^{27}$ that decentralisation has been put on an irreversible track, this level of pussyfooting in the application of the law lends credence to critics who charge the government with the absence of the political will to effectively decentralise. The former ask what guarantees there are that legal instruments of application will be signed if dispositions of the law (that are applicable without more) remain a dead letter to date.

\section{Conclusion}

Through the brief statement of objectives of decentralisation, it is apparent that the latter is a process. Whether it is to alleviate poverty, to provide essential services to the population, fight corruption through good governance and the active involvement of the population in the affairs of the city or development, decentralisation takes time. In Cameroon, the decentralisation laws of 2004 represent a framework (albeit incomplete) on which to con- 
struct decentralised local entities that reflect the social and cultural specificities of the country without turning a blind eye on modernity. The promotion of local development and good governance seem to be the main thrust of these new laws. It was noted earlier that the laws in themselves are very advanced as they devolve powers to local entities that still have to be trained on how to manage the said power. In spite of the constraints identified, the present state of the law and of stakeholders and recent developments seem to show that decentralisation has taken an irreversible forward turn here.

More than two years after the decentralisation laws were promulgated, there are no signs of changes that can be represented by empirical data on how councils and regions have performed under the new laws. Finding and recording any such performance is difficult or premature, because the legal landscape still awaits instruments that will render the new laws applicable. However, a lesson that is not lost here is its portrayal of the serious limitations and frustrations that parliament creates when it votes laws - in the form of legal frameworks like the 2004 decentralisation laws - which leave many gaps (without which the laws are inapplicable) to be filled by the Executive without a time-frame. Parliament is only effectively capable of ensuring the pace of the application of reform agenda if such a practice is cut to the barest minimum.

The 2004 laws and the opportunities they present alone may not however suffice. The success of this reform agenda requires, inter alia, the manifestation of a strong political will to decentralise, time, resources, because 'true decentralisation only occurs when local decision-making bodies have control over financial resources' (Midgley 1986: 33), active involvement of all the stakeholders, concrete institutional and human capacity building at all levels to enable local authorities to fully assume their new roles, tasks and duties. The dangers of the failure to accompany the new laws with the transfer of means and effectively and expeditiously build the capacities of beneficiaries and stakeholders of powers devolved by the new decentralisation laws are comparable to those that come with say the gift of a car to an untrained and unlicensed driver who in turn hits the road. The benefits now, of embarking on organisation and concentration on human and institutional capacity building (in order to well found decentralisation) are however immeasurable.

\section{Notes}

1. With the passing of a series of laws on rights and freedoms.

2. End of Year 2002, 2003 and 2004 policy speeches to the Cameroon nation by the President of the Republic. 
3. Law $\mathrm{N}^{\circ} 2004 / 017$ of July 22, 2004 on the Orientation of Decentralisation; Law $\mathrm{N}^{\circ}$ 2004/018 of July 22, 2004 laying down rules applicable to Councils; Law N ${ }^{\circ}$ 2004/019 of July 22, 2004 laying down rules applicable to Regions.

4. Law $N^{\circ} 2004 / 017$ of July 22, 2004 on the Orientation of Decentralisation, chapters 1-3. Councils number 360 as at 2007.

5. Ibid, art. 6; Law $\mathrm{N}^{\circ}$ 2004/018 of July 22, 2004 to lay down rules applicable to Councils, articles 4-7.

6. Arrêté $\mathrm{N}^{\circ} 130 / \mathrm{CAB} / \mathrm{pm}$ du 6 octobre 2006 portant création, organisation et fonctionnement d'un comité de concertation pour la mise en œuvre de la décentralisation.

7. Netherlands Development Organisation (SNV).

8. Swiss Association for International Co-operation (Helvetas).

9. German Development Cooperation (GTZ), German Development Service (DED) and Fredrich Ebert Foundation (FES), German Development Bank (KFW).

10. Centre, Far North and West per unpublished minutes Négociations Intergouvernementales germano/camerounaise, mai 2004.

11. Orientation Law supra, art. 66.

12. Author's translation from the French.

13. P. O. Box 3799 Yaoundé, Tel: + 2372221 3140, Fax +2372220 5520.

14. P. O. Box 12977 Douala, Tel: +2373342 76878; www.ADEID.org.

15. P. O. Box 11955 Yaoundé, Tel: +2372222 4682, www.Saild.org.

16. www.zenu.org.

17. www.dschangshuss.net.

18. Articles 66-77 Orientation law.

19. Law No 2006/004 of July 14, 2006 to lay down conditions governing the election of regional councillors.

20. It is submitted that the result has been the current accentuation of poverty in contrast with the case of the now wealthy South East Asian countries where the institution of competitive economies preceded liberalisation.

21. Art 91 of the 1974 law as amended by law No 95/21 of August 8, 1995.

22. Decree No 2000/365 of December 11, 2000 and very recently by Decree No 2006/182 of may 31, 2006.

23. Author's translation from the French article by J. Boudine, 'La distinction entre collectivité locale et collectivité territoriale. Variation sémantique ou juridique?', 1992, R.D.P., p. 179

24. For an example of the bottom-up approach that gives voice to the population here, see: 'Decentralisation in Mali: Putting policy into practice', SNV \& CEDELO Bulletin $\mathrm{N}^{\circ} 362$ (2004) pages 18-22.

25. Cameroon, Décision N 05-232/MINEFI/CAB of 16 May 2005.

26. Section 177 of Law No 74/23 of December 5, 1974 and the subsequent amendments thereto.

27. Decree No. 2002/216 of 24 August 2002 reorganising the Government of Cameroon. 


\section{Acknowledgements}

The author wishes to record his thanks to Professor Fondo Sikod of the Faculty of Management and Economic Sciences, University of Yaoundé II at Soa for useful comments made to an earlier draft of this paper.

\section{References}

\section{Laws and legal instruments}

Constitution of January 18, 1996 of Cameroon.

Decree $N^{\circ} 77 / 418$ of 24 October 1977 creating and organising the Local Government Centre, known by its French acronym 'CEFAM'.

Decree No 2000/365 of December 11, 2000 reorganising FEICOM.

Decree No 2006/182 of May 31, 2006 reorganising FEICOM.

Decree $N^{\circ}$ 2002/216 of August 24, 2002 to reorganise the government of Cameroon Finance Law of The Republic of Cameroon, 1962.

Law $N^{\circ} 74 / 23$ of 5 December 1974 to organise councils and subsequent amendments thereto; Law $\mathrm{N}^{\circ}$ 90/062 of December 19, 1990 to grant a special waiver to public health units in financial matters.

Law $N^{\circ} 2004 / 17$ of July 22, 2004 on the Orientation of Decentralisation.

Law N ${ }^{\circ} 2004 / 18$ of July 22, 2004 to lay Down rules applicable to Councils.

Law N ${ }^{\circ} 2004 / 19$ of July 22, 2004 to lay Down Rules applicable to regions.

Law No 2006/004 of July 14, 2006 to lay down conditions governing the election of regional councillors.

\section{Works, articles and other sources}

Arrêté $\mathrm{N}^{\circ}$ 130/CAB/pm du 6 octobre 2006 portant création, organisation et fonctionnement d'un comité de concertation pour la mise en ouvre de la décentralisation.

Budine, J., 1992, 'La distinction entre collectivité locale et collectivité territoriale. Variation sémantique ou juridique?', R.D.P., p. 179.

Cheema, D. S. \& Rondinelli, D. A., eds., 1983, Decentralisation and government, Beverley Hills CA: Sage.

'Decentralisation in Mali: Putting Policy into Practice', 2004, SNV \& CEDELO Bulletin $\mathrm{N}^{\circ} 362$.

End of Year 2002, 2003 and 2004 policy speeches to the Cameroon nation by President Paul Biya at www.cameroon-tribune.cm.

Esman, M. J. \& Uphoff, N. T. 1984, Local organisations: Intermediaries in Rural Development, Ithaca, New York, Cornell University Press.

Guimdo, Bernard Raymond, 1998, 'Les bases Constitutionnelles de la décentralisation au Cameroun’, 29 Revue Générale de Droit, Université d'Otawa, 79-100 at p. 87.

Interview with His Excellency the Minister in charge of decentralisation (MINATD) accorded to the National Daily, Cameroon Tribune $\mathrm{N}^{\circ}$ 8426/4625 of 2 September 2005, p. 4. 
Lemarchand, R., 1998,. 'La face cachée de la décentralisation: réseaux, clientèles et capital social', in Bulletin IPAD, Décentralisation, pouvoirs sociaux et réseaux Sociaux, No 16, LIT, p. 9-18.

Midgley, James, 1986, Community participation, Social Development and the State, London: Methuen, pp 13, 32-33.

Négociations Inter-gouvernementales germano/camerounaises, mai 2004, (unpublished minutes).

Le Quotidien Mutations (Newspaper) of August 5, 2005 (report in French of Junior Binyam on FEICOM Board Meeting).

Sawadogo, A. A., 2001, L'Etat Africain face à la décentralisation, Paris: Editions Karthala, p. 197.

Totté, Marc, Dahou, Tarik et Billaz, René, 2003, La Décentralisation en Afrique de l'Ouest: Entre la politique et le développement, Paris: Karthala, p. 10.

Troper, M., 1980, 'Libre administration et théorie générale du droit', La Libre administration des collectivités territoriales, Paris, Economica, 1980, p. 62.

UNDP, 19999, Decentralisation: a sampling of definitions, October.

Wunsch, J. S. \& Olowu, D., eds., 1990, The failure of the Decentralised State and Self Governance in Africa, Goulder Westview Press.

www.adeid.org

www.pdm-net.org/Newsite/french

www.saild.org

www.mairiesducameroun.net.

www.cameroon-tribune.cm

www.dschangshuss.net

www.zenu.org

www.Allafrica.com

www.quotidienmutations.net

www.undp.org 